Primljen / Received: 21.11.2013. Ispravljen / Corrected: 13.3.2014.

Prihvaćen / Accepted: 12.4.2014. Dostupno online / Available online: 10.6.2014.

\section{Strength and ductility of concrete confined circular columns}

\section{Authors:}

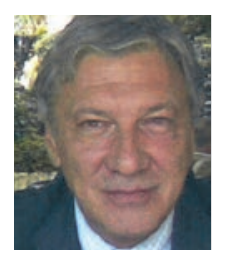

\section{Dušan Najdanović, Branko Milosavljević}

Preliminary note

\section{Strength and ductility of concrete confined circular columns}

The design procedure of capacity and ductility on the concrete columns with circular cross section depending on the amount of the confining reinforcement is presented in this paper. The stress-strain model in which the longitudinal compressive strain of the concrete at failure is corresponding to the first fracture of the transverse reinforcement, is presented. The cross section capacity and the ductility factor corresponding to the longitudinal force and stirup distance is analyzed. Use of the similar design procedure on concrete-filled steel tubular columns and in strengthening of columns using still straps or FRP is possible.

Key words:
circular columns, transverse reinforcement, limit bearing capacity, curvature, ductility

Prethodno priopćenje

Dušan Najdanović, Branko Milosavljević

\section{Nosivost i duktilnost kružnih ab stupova ovijenih poprečnom armaturom}

Prikazan je postupak proračuna nosivosti i duktilnosti kružnih stupova u funkciji količine poprečne armature. Na jezgri presjeka je primijenjen dijagram naprezanja tlačnog betona s utjecajem poprečnog tlaka od spone, a granična uzdužna deformacija odgovara trenutku Ioma poprečne armature. Analizirana je nosivost presjeka i koeficijent duktilnosti kuta zaokreta ovisno o intenzitetu normalne sile i razmaku spona. Sličan postupak proračuna moguće je primijeniti i na cijevi ispunjene betonom kao i u slučajevima sanacije stupova prstenastim čeličnim limovima ili FRP tkaninama.

Ključne riječi:

kružni stupovi, poprečna armatura, granična nosivost, kut zaokreta, duktilnost

Vorherige Mitteilung

Dušan Najdanović, Branko Milosavljević

\section{Festigkeit und Duktilität von Rundsäulen aus Stahlbeton mit Umschnürungsbewehrung}

In dieser Arbeit ist das Berechnungsverfahren zur Tragfähigkeit und Duktilität von Betonsäulen kreisförmigen Querschnitts in Bezug auf den Anteil an Umschnürungsbewehrung dargestellt. Die Spannungs-Dehnungs-Beziehung, bei der dem Betonversagen entsprechende longitudinale Druckverformungen mit dem ersten Versagen der Querbewehrung übereinstimmen, ist dargestellt. Die Kapazität des Querschnitts und der Duktilitätsfaktor sind hinsichtlich der Längsbelastung und des Bügelabstandes analysiert. Ähnliche Berechnungsverfahren können für betongefüllte Stahlrohrsäulen und bei der Verstärkung von Stützen mit ringförmigen Stahlblechelementen oder Stoffen aus FRP angewandt werden. 


\section{Introduction}

Proper and adequate confinement of column core with transverse reinforcement enables achievement of the required level of plastic rotation and an appropriate bearing capacity, even at high angles of curvature. In order to ensure an appropriate resistance to seismic forces, it is especially significant to provide a sufficient quantity of transverse reinforcement in column areas where plastic hinges may be expected, as this will increase the carrying capacity and ductility, while at the same preventing local buckling of longitudinal reinforcement, and fracture due to transverse forces. In case of complex bending with a normal compressive force, the compressed zone of concrete crosssection increases, and ductile properties of the column are mainly attained through higher nonlinear deformations of the compressed part of concrete. Compared to the unconfined cross-section, the concrete resistance to compression may be increased by more than $100 \%$, and the increase in ductility of the curvature angle, expressed through increase in limit strain of concrete, is also significant and may attain up to $50 \%$.

The spatial state of stress in the concrete core of the column confined with stirrups is maintained until failure of transverse reinforcement, either by attainment of the limit $\sigma_{\nu}$ or by stirrup opening in case its ends were poorly anchored, i.e. when a sufficient overlap at stirrup ends is not provided. In such a case the failure of the reinforced-concrete column is practically instantaneous.

The efficiency of transverse reinforcement confining the concrete cross-section is mostly dependent on two factors: intensity of stress of confinement realized in transverse reinforcement, and distribution of transverse compression acting in this case on the surrounding concrete. The first factor is directly related to the stress in transverse reinforcement and the quantity of transverse reinforcement, which is usually expressed via the volume of reinforcement and volume of core of the confined concrete. The second factor is related to the uniformity of distribution of transverse compression across the surrounding concrete, and is greatly dependent on the cross-sectional geometry. For the same percentage of transverse reinforcement, circular stirrups enable, compared to rectangular or square ones, more efficient confinement of the cross-sectional core, because the transverse pressure generated by such stirrups and acting on concrete is more uniformly distributed due to circular geometry of columns. In this respect, the $\sigma-\varepsilon$ curve of the confined compressed core of concrete is directly dependent on the shape of cross section.

\section{Shape of $\sigma-\varepsilon$ curve for the confined compressed concrete core}

The stress - strain diagram for the confined concrete of circular cross-section has been proposed by a number of authors, but the most successful of them is the one developed by Mander Priestley and Park [1]. Their model is based on experimental results obtained on column samples of real-life dimensions through which a great number of relevant parameters is obtained. Basically, this model is valid for monotonous increase of load, but can also be used for determining limit carrying capacity of columns subjected to complex bending with a normal compressive force. Stress diagrams for the confined and unconfined concrete crosssection, based on this model, are presented in Figure 1.

The strain $\varepsilon_{c u 2}$ shown in Figure 1 denotes concrete strain at the achieved compressive strength of the unreinforced (unconfined) concrete, $f_{c o}$. The compressive strength of concrete confined with reinforcement $f_{c c}$ (concrete confinement) is given as a function of compressive strength of unreinforced concrete $f_{c o}$ and the effective cross-sectional stress $f_{p}$ which is due to confinement of cross-section with transverse reinforcement [1]:

$f_{c c}=f_{c o} \cdot\left[-1.254+2.254 \sqrt{1+\frac{7.94 \cdot f_{p}}{f_{c o}}}-\frac{f_{p}}{f_{c o}}\right]$

The effective cross-sectional stress $f_{p}$ by which the crosssection core is confined is defined from the following expression:

$f_{p}=f_{p}^{\prime} \cdot k_{e}$

where:

$f_{p}^{\prime}$ - transverse confinement stress,

$k_{e}$ - coefficient of effectiveness of confinement with transverse reinforcement.

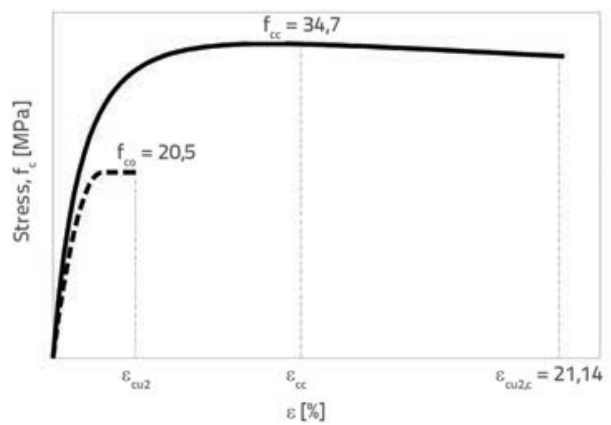

Figure 1. Stress diagram for unconfined concrete and concrete confined with transverse reinforcement [1]

The continuous distribution of stress $f_{p}$ along the concrete core surface bounded with transverse reinforcement can be assumed at the failure phase, as shown in Figure 2.a. a)

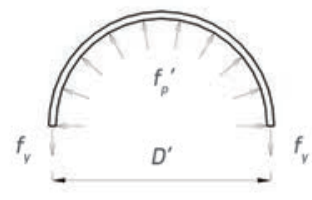

b)

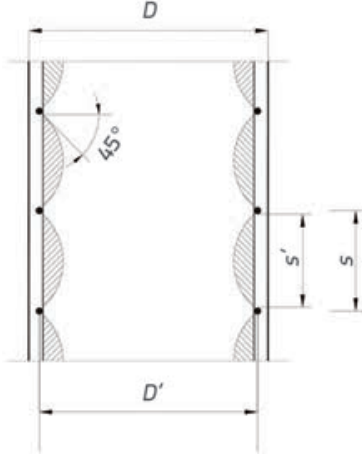

Figure 2. Envelopment with transverse reinforcement - distribution of stress $f_{p}^{\prime}$ : a) along the cross section; b) along the pier height 
The expression that is a function of coefficient of transverse reinforcement volume $\omega_{\text {wd }}$ and nominal steel relaxation stress $f_{y}$, is obtained from the equilibrium condition, for transverse confinement stress:

$f_{p}^{\prime}=\frac{1}{2} \cdot \omega_{w d} \cdot f_{y}$

The coefficient of transverse reinforcement volume is defined from the expression:

$\omega_{\mathrm{wd}}=\frac{4 \cdot \mathrm{A}_{\mathrm{st}}}{\mathrm{D} \cdot \mathrm{s}}$

where:

$A_{\text {st }}$ - cross-sectional area of one stirrup,

$s$ - axial spacing of transverse reinforcement.

As shown in Figure 2b, the distribution of transverse stress along the column height between two transverse reinforcing bars is adopted in form of the second order parabola, with the initial tangent at an angle of $45^{\circ}$. In this way, a part of the concrete column marked with hatched area in Figure $2 b$ does not transfer the stress due to confinement, and so the effective cross-sectional area of column is obtained from the expression:

$A_{\mathrm{ef}}=\frac{\pi}{4} \cdot D^{\prime 2} \cdot\left(1-\frac{s^{\prime}}{2 \cdot s}\right)^{2}$

With the effective cross-sectional area defined in this way, the coefficient of effectiveness of confinement with transverse reinforcement, $k_{\text {ew }}$ can be calculated using the following expression:

$k_{\text {ew }}=\left(1-\frac{s^{\prime}}{2 \cdot s}\right)^{2}$

The limit strain value, $\varepsilon_{\text {cuz, }}$ presented in Figure 1 , which is achieved at the failure of confined concrete, can be defined using the following empirical expression [2]: $\varepsilon_{\mathrm{cu} 2, \mathrm{c}}=0.004+0.03 \cdot \omega_{\mathrm{wd}} \cdot \mathrm{f}_{\mathrm{y}}$

The limit strain of confined concrete, $\varepsilon_{\text {cuz, } c}$ according to expression (7), is actually achieved at first fracture of the transverse reinforcement, when the carrying capacity of the confined concrete core suddenly drops due to reduced action of the spatial state of stress. This has also been confirmed by more recent papers that are based on the analysis of energy balance of cross-sectional cores confined with transverse reinforcement (taking into account the fact that the increase in energy absorbed by confined core is closely related to the energy retained by transverse reinforcement up the limit of failure).

\section{Calculation of moment - curvature angle diagram for confined section}

The following numerical calculation procedure was used to enable application of the mentioned procedure for making the confined-concrete stress diagram in the analysis of bearing capacity and ductility of circular columns, with the purpose of forming the bending moment - curvature angle diagram. The calculation is conducted using an original computer program, for the section of known dimensions and reinforcement, and with the defined external normal force $\mathrm{N}_{\mathrm{Ed}}$. The circular crosssection, shown in Figure 3, is formed of three basic parts:

- protective concrete cover (marked with 1)-calculated from the edge of cross-section to circular stirrup axis,

- longitudinal reinforcement (marked with 2) - for calculation purposes it is approximated with a continuous ring, and

- internal concrete core (marked with 3) - confined with stirrups.

For the given cross-section and reinforcement, the procedure described in Section 2 is used to calculate the compressive strength $f_{c c}$ and limit strain $\varepsilon_{c u z c}$ of concrete confined with reinforcement, based on expressions (1) - (7). This is followed

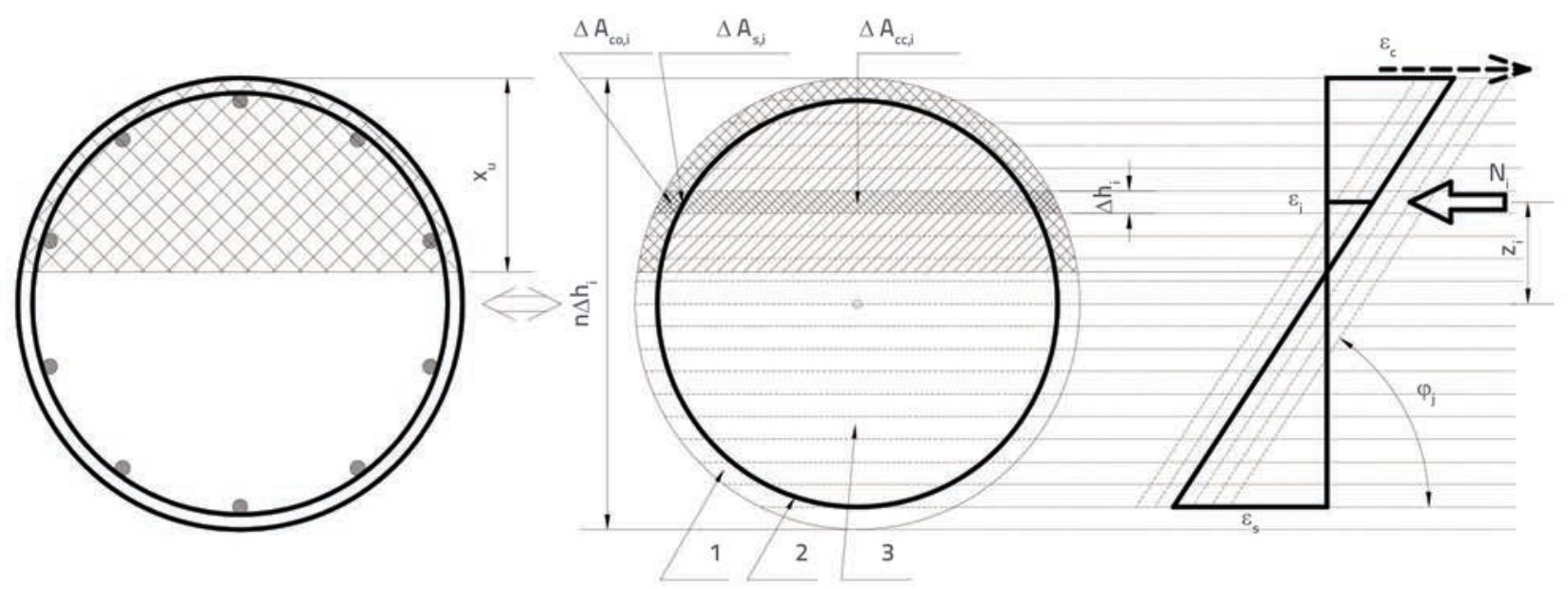

Figure 3. Calculation of the cross-section carrying capacity moment for a given curvature angle and an external normal force 
by the design of stress diagrams for confined concrete (marked with solid line in Figure 1), and conventional diagram for unconfined concrete in form of the second-order parabola and straight line, with limit strain in concrete amounting to 3.5\% (marked with dashed line in Figure 1).

The cross section carrying capacity moment is calculated for each selected value of curvature angle (from zero toward maximum value, with the desired increment). A numerical procedure known as the Finite Layer Approach is used. In this respect, the cross-section is divided into an $n$ number of horizontal strips $\Delta \mathrm{h}_{\mathrm{i}}$ in height (Figure 3). The areas of $\Delta \mathrm{A}_{c 0, i}$ (protective concrete cover), $\Delta \mathrm{A}_{\mathrm{s}, \mathrm{i}}$ (reinforcement ring) and $\Delta \mathrm{A}_{\mathrm{cc}, \mathrm{i}}$ (confined concrete), are calculated for each strip. The strain $\varepsilon_{c}$ is varied for each selected curvature angle $\varphi_{\text {. }}$. Strain values along strips $\varepsilon_{c}$ and stress values in individual parts of cross section are calculated for each variation:

- $f_{c o, i}$ for $0<\varepsilon_{i}<3,5 \%$, the value of fco,i is calculated from the conventional diagram for unconfined concrete (marked with dashed line in Figure 1). In the contrary case, $f_{c o, i}=0$.

- $f_{s, i^{\prime}}$ for which the usual bilinear stress-strain diagram for steel is applied, without strain limitation for tensile steel,

- $\mathrm{f}_{\mathrm{cc,i}}$ for $\varepsilon_{\mathrm{i}}>0$ the value of $\mathrm{fcc}, \mathrm{i}$ is calculated from the stress diagram for confined concrete (marked with solid line in Figure 1). For the tensioned part of cross-section $f_{c c, i}=0$.

Appropriate values of force $\mathrm{N}_{\mathrm{i}}$ are defined from calculated stress values along strips:

$$
N_{i}=f_{c o, i} \cdot \Delta A_{c o, i}+2 \cdot f_{s, i} \cdot \Delta A_{s, i}+2 \cdot f_{c c, i} \cdot \Delta A_{c c, i}
$$

Forces $\mathrm{N}_{\mathrm{i}}$ are added along all strips and, in this way, the internal normal force in cross-section is obtained. The $\varepsilon_{c}$ variation is conducted until proper balancing of the internal and external normal force in cross section, provided always that the maximum strain in confined concrete must not be greater than the limit strain for concrete $\varepsilon_{c u 2, c^{\prime}}$ as defined by expression (7). Once the balanced state is reached, bending moments are integrated along strips, by adding moments $\mathrm{N}_{i} \cdot \mathrm{z}_{\mathrm{i}}$ around the centre of the cross-section. The limit curvature angle $\varphi_{\mathrm{u}^{\prime}}$ is the last one for which the balanced state in cross-section can be achieved, taking into account described conditions.

\section{Proportion of confined and unconfined parts of cross-section at the contact between bending moment and curvature angle}

The case of circular cross section $500 \mathrm{~mm}$ in diameter, concrete class C25/30, reinforced with longitudinal reinforcement consisting of $10 \emptyset 16 \mathrm{~mm}$ bars, and stirrups $10 \mathrm{~mm}$ in diameter spaced at $\mathrm{s}=50 \mathrm{~mm}$, with the protective concrete cover $\mathrm{a}=$ $30 \mathrm{~mm}$, was selected for analysing the proportion of confined and unconfined parts in concrete section, and longitudinal reinforcement, with regard to the bending moment and angle of curvature of transverse cross-section, at a constant normal force. As the maximum angle of curvature the cross-section can achieve at the moment of fracture greatly depends on the value of normal force, the loading of the column with the constant normal force of $\mathrm{N}_{\mathrm{Ed}}=1500 \mathrm{kN}$ was adopted in this case which, in the dimensionless form, amounts to $v_{d}=N_{E d}$ / $N_{u}=0,37$ with respect to the limit axial force of concrete section fracture of $N_{u}=A_{c} f_{c d^{*}}$.

Four curves are presented in Figure 4 in order to facilitate estimation of the proportion taken by each part of cross section in the carrying capacity and ductility: the curve marked with 1 represents the part taken by the confined concrete core, the curve 2 is the part taken by longitudinal reinforcement, and the curve 3 is the part representing the protective concrete layer. The moment - curvature curve is marked with 4 . Computed stress - strain diagrams for the confined part and unconfined part of concrete section are presented in Figure 1.

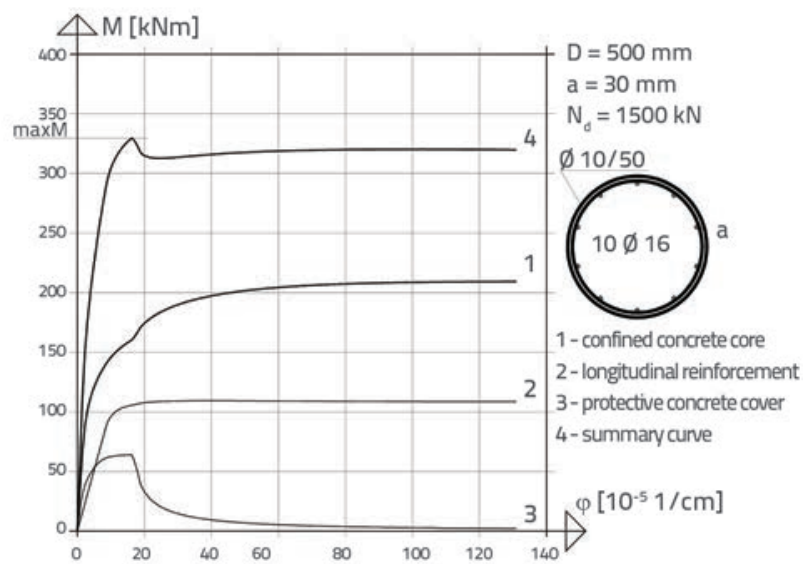

Figure 4. Curvature - moment diagram (4) at N = const. for circular cross-section, with curves representing

The protective concrete cover, Curve 3, attains its maximum carrying capacity at a relatively small curvature of cross section, Figure 4. Then the carrying capacity suddenly drops and, due to geometric properties of cross-section, it gradually fully reduces at further increase of the angle of curvature. An additional carrying capacity and greater angle of curvature is mostly obtained through the confined concrete core, Curve 1 , where the carrying capacity is still not exhausted. At the summary diagram, Curve 4, a smaller drop in carrying capacity, as related to moment, can be observed in the protective concrete cover once the limit deformation is achieved.

\section{Carrying capacity and ductility of confined circular columns}

\subsection{Influence of confinement on the carrying capacity of columns}

Under the influence of a normal force, the compressive strength in concrete core, and hence the carrying capacity of column, increases with an increase in the column core confinement 
rate. The maximum bending strength of cross-section is achieved at a lower angle of curvature of cross-section, when the protective concrete cover is still efficient (maxM in Figure 4). At further increase in curvature, the protective action of concrete cover disappears, the static height of cross-section reduces, and the bending strength also reduces. The analysis of various combinations of reinforcement with stirrups, and normal force intensities, reveals that in the majority of cases the increase of compressive strength of concrete in a highly confined core does not significantly contribute to the bending strength.

Therefore, the confinement of cross-section with stirrups contributes to a much greater extent to the increase in carrying capacity of columns subjected to normal force, while the increase of carrying capacity with respect to bending moment is much less pronounced, and is practically negligible.

\subsection{Influence of confinement on the ductility of columns}

In order to ensure a ductile behaviour of structures, especially when they are subjected to seismic forces, all plastic hinge formation zones (in case of columns, these zones are at column ends) must have an appropriate ductility, as this will enable a high plastic rotation capability. The $\mu_{\phi}=\varphi_{v} / \varphi_{\psi}$ ratio, also known and the curvature ductility factor, is used for measuring ductility. In this ratio, $\varphi_{u}$ is the curvature angle at fracture, and it occurs either at the moment of stirrup fracture, or when in the post elastic zone the carrying capacity - as related to bending moment - drops to $85 \%$ of the value of moment at the limit of elasticity. The angle of curvature $\varphi_{y}$ is the angle of curvature at the moment the elastic failure of longitudinal reinforcement under tensile stress is achieved for the first time.

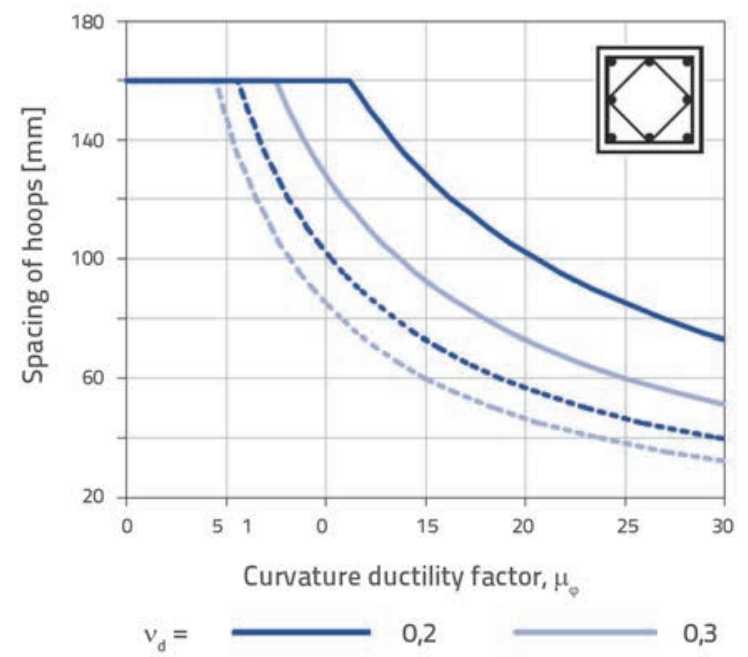

Taking into consideration the need to achieve an appropriate column ductility during an earthquake action, the Eurocode 8 $[3,5]$ specifies the curvature ductility factor, $\mu_{\varphi}$ as a function of the basic behaviour factor, $q_{0^{\prime}}$ and, for structures with grater rigidity, the structure's basic oscillation period:

$\begin{array}{ll}\mu_{\varphi}=k\left[2 q_{0}-1\right] & \text { for } T_{1} \geq T_{C} \\ \mu_{\varphi}=k\left[1+2\left(q_{0}-1\right) T_{C} / T_{1}\right] & \text { for } T_{1}<T_{C}\end{array}$

where:

$k-1,5$ (B class reinforcement)

$k-1,0$ (C class reinforcement)

$T_{c}$ - top limit of the spectral-curve constant acceleration interval

$T_{1}$ - structure oscillation period in the first mode.

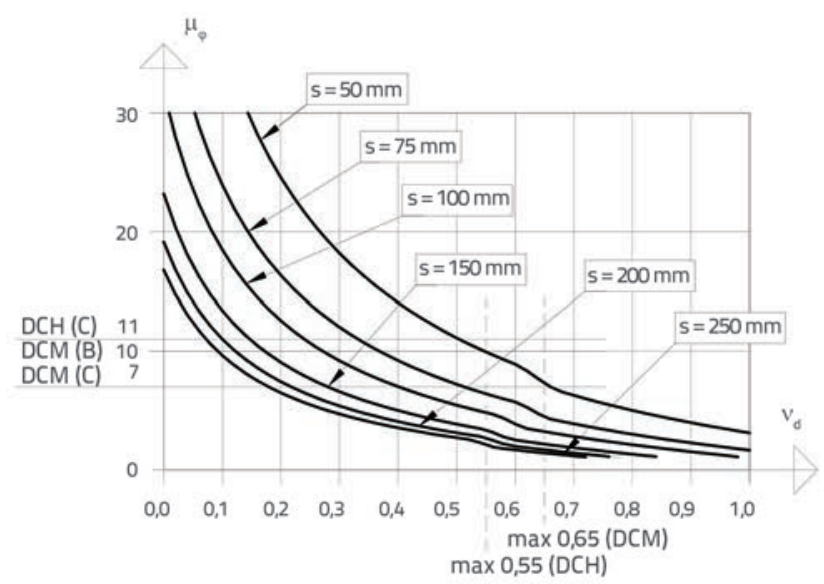

Figure 5. Curvature ductility factor $\left(\mu_{\phi}\right)$ as a function of normalized normal force $\left(v_{d}\right)$ for different intervals of stirrups $(s)$ in column of circular cross-section

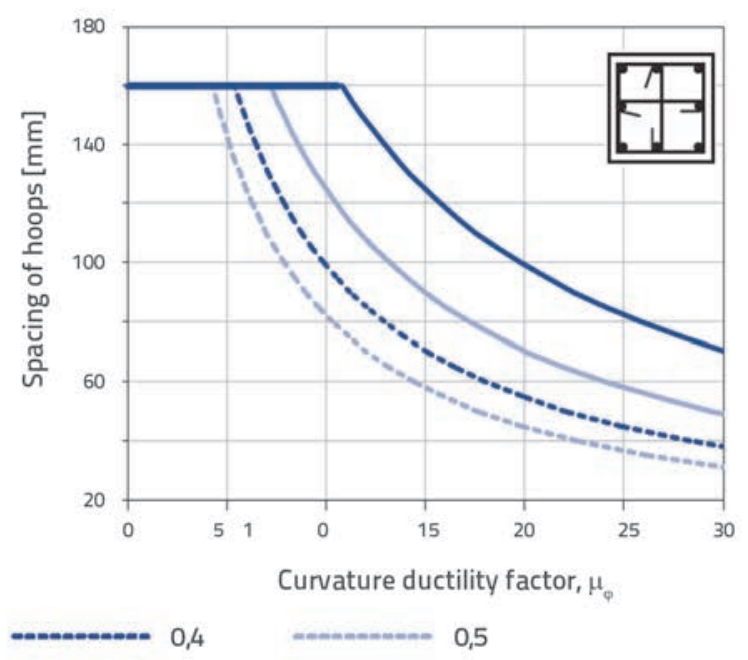

Figure 6. Example of diagram for determining the curvature ductility factor as a function of stirrup intervals for column $400 / 400 \mathrm{~mm}$ [5] (in diameter: $12 \mathrm{~mm}$ ) 
These factors are specified for the area at the bottom of primary columns (at the contact with foundations) in case of structures of medium ductility (DCM), and at all ends of all primary columns (in zones of possible occurrence of plastic hinges), for structures with high ductility (DCH). For that reason, the curvature ductility factor for columns of circular cross-section is analysed in the paper as a function of the normalised normal force for different distances between stirrups. The corresponding diagrams are presented in Figure 5. These diagrams clearly show that a high and reliable non-elastic deformation capacity can be ensured by strong confinement of columns with transverse reinforcement, even at higher intensities of normal force.

For the case of multistorey frames with several bays, when the building is regular and when periods are $T_{1} \geq T_{c^{\prime}}$ Figure 5 shows required values of the curvature ductility factor $\mu_{\phi}$ for buildings with high DCH (C) and medium DCM (B) or (C) ductility, where $(B)$ and $(C)$ are reinforcement classes. Only the class $C$ reinforcement may be used for high-ductility buildings.

In addition, the Eurocode 8 also requires that the maximum value of the normalised normal force be limited to $v_{d}=0,65$ for DCM structures, i.e. to $v_{d}=0,55$ for DCH structures, cf. Figure 5 . According to EC8 provisions relating to required curvature ductilities, the Manual for the seismic design of steel and concrete buildings in Eurocode 8 [5] contains a series of diagrams showing link between the curvature ductility factor and stirrup intervals for individual geometrical properties of cross-section of rectangular columns, at different levels of the nominal normal force $v_{d^{*}}$

An example of diagram from the mentioned Manual, for column measuring $400 / 400 \mathrm{~mm}$ in cross-section, and for two methods of transverse reinforcement, is shown in Figure 6.

Based on the calculation presented in this paper, appropriate diagrams (Figure 7) were made for the column of circular cross-section.

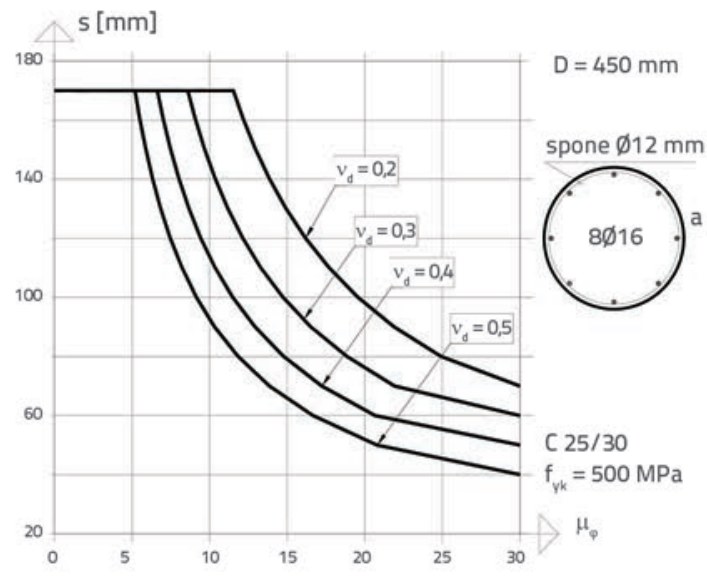

Figure 7. Example of diagram for determining the curvature ductility factor as a function of stirrup intervals for circular column $450 \mathrm{~mm}$ in diameter
Diagrams shown in Figure 7 were made for a circular column which corresponds, by its cross-sectional dimensions and material properties, to the column presented in Figure 6. Curves shown in this example are similarly shaped as the curves given in Figure 6 for the column of rectangular cross section, and similar curvature ductility factors are obtained in both cases. It should be noted that two stirrups $12 \mathrm{~mm}$ in diameter were used for the confinement of rectangular column, while only one stirrup was used for circular column, which is a known effect of efficiency that is achieved by confinement with circular stirrups. It can be concluded that the adoption of column of circular cross-section is a good solution in cases when higher curvature ductility is required. It is quite easy to use such diagrams in the design of structures. As series of diagrams can relatively easily be made for different cross-sections and longitudinal reinforcement percentages (using procedure shown in Section 3), the designer only needs to select an appropriate diagram, and read the required interval of stirrups $s$ (Figure 7) to be adopted, for the level of normal force in the column $v_{d}$ and the required curvature ductility factor $\mu_{\phi}$

The presented calculation procedure can also be applied in the analysis of carrying capacity of a pipe filled with concrete, and also in case when the repair of the existing circular columns is made by confinement using sheet steel rings or FRP sheets, which can greatly increase the carrying capacity and improve ductility of existing columns. Composite materials made of glass or carbonic fibres are currently increasingly used for this kind of remedial activities, $[4,8]$.

\section{Conclusion}

An original computer program founded on stress diagrams and confined concrete limit strain expressions, and based on the numerical method known as the Finite Layer Approach, was developed as a means to calculate the carrying capacity and ductility of circular reinforced-concrete columns confined with reinforcement. The result of this calculation can be expressed as a diagram showing relationship between the bending moment and cross-section curvature. Just like in case of columns of quadratic and rectangular cross-section, a high and reliable capacity of available non-elastic deformations can also be ensured for circular columns by strong confinement of columns with transverse reinforcement, even in case of high intensities of normal force. Using this diagram, it can be concluded from the analysis of contribution of individual parts of cross section at limit load that the confinement of the circular section core with strong stirrups not only increases its ductility, but also significantly increases its resistance to normal force. However, in such cases the increase of resistance to bending is practically negligible. The quantity of transverse reinforcement needed to achieve the required level of ductility increases with the reduction of percentage 
of reinforcement with longitudinal reinforcement, and with an increase in thickness of the protective concrete cover.

The analysis presented in the paper can be used to make diagrams for the calculation of curvature ductility depending on the normalized normal force in cross-section, and depending on the distance between stirrups. These diagrams can be applied in practice for dimensioning ductile structures with columns of circular cross-section.

These conclusions are equally valid for pipes filled with concrete, and also for the existing circular columns that have to be remedied by confinement with sheet steel rings or FRP sheets.

\section{REFERENCES}

[1] Mander, J.B., Priestley, M.J.N., Park, R.: Theoretical Stress-Strain Model for Confined Concrete, Journal of Structural Engineering, Vol. 114, No. 8, pp. 1804-1826, August 1988.

[2] Scott, B.D., Park, R., Priestley, M.J.N.: Stress-Strain Behavior of Concrete Confined by Overlapping Hoops at Low and High Strain Rates, ACI Structural Journal, V. 79, No. 1, pp. 13-27, Jan.-Feb. 1982.

[3] General rules, seismic actions and rules for buildings, Eurocode 8: Design of structures for earthquake resistance, Part 1. 2004

[4] Saadatmanesh, H., Ehsani, M.R., Li, M.W.: Strength and Ductility of Concrete Columns Externally Reinforced with Fiber Composite Straps, ACl Structural Journal, V. 91, No. 4, pp. 434-447, July.August. 1994.
[5] The Institute of Structural Engineers: Manual for the seismic design of steel and concrete buildings in Eurocode 8, may 2010.

[6] Paultre, P., Légeron, F.: Confinement Reinforcement Design for Reinforced Concrete Columns, Journal of Structireal Engineering, may 2008

[7] A. M. el Fattah: Behavior of Concrete Columns under various Confinement Effects, Abstract of a Dissertation, M.S., Kansas State University, 2012

[8] Pantelides, C.P., Zihan, Y., Reaveley, L.D.: Shape Modification of Rectangular Columns Confined with FRP Composites, Report No. UT-05.03, Department of Transportation Research and Development Division - University of Utah, USA, December 2004 